\title{
Factors associated with the use of alcohol and drugs by pregnant women
}

\author{
Fatores associados ao uso de álcool e drogas por mulheres gestantes
}

Priscilla Nunes Porto ${ }^{1}$, Silier Andrade Cardoso Borges ${ }^{1}$, Anne Jacob de Souza Araújo ${ }^{1}$, Jeane Freitas de Oliveira ${ }^{1}$, Mariza Silva Almeida ${ }^{1}$, Mayara Novais Pereira ${ }^{1}$

Objective: to verify the association between sociodemographic conditions and the involvement of pregnant women with drugs. Methods: a cross-sectional study was carried out with 268 pregnant women in a public maternity hospital, through an interview. For the bivariate analysis Fisher's Exact Test and odds ratio with 95\% confidence interval were used. Results: statistically significant associations were observed between the use of psychoactive substances by pregnant women and schooling $(\mathrm{p}=0.017)$, race $(\mathrm{p}=0.020)$ and housing condition $(p=0.014)$. Conclusion: it was evidenced that different factors contribute to the occurrence of vulnerability to health among pregnant women, mainly resulting from the integration of individual and social aspects.

Descriptors: Drug Users; Pregnant Women; Social Vulnerability.

Objetivo: verificar a associação entre as condições sociodemográficas e o envolvimento de gestantes com drogas. Métodos: estudo transversal realizado com 268 gestantes em uma maternidade pública, por meio de entrevista. Para a análise bivariada utilizou-se o Teste Exato de Fisher e odds ratio com intervalo de confiança de 95\%. Resultados: foram observadas associações estatisticamente significantes entre o uso de substâncias psicoativas pelas gestantes e a escolaridade $(p=0,017)$, raça $(p=0,020)$ e condição de moradia $(p=0,014)$. Conclusão: evidenciou-se que diferentes fatores contribuem para a ocorrência de vulnerabilidade à saúde entre gestantes, sobretudo resultante da integração de aspectos individuais e sociais.

Descritores: Usuários de Drogas; Gestantes; Vulnerabilidade Social.

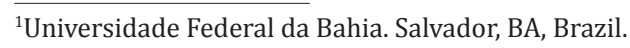




\section{Introduction}

The consumption and commerce of psychoactive substances are behaviors that can impact on the life of the people who adopt them, as well as for their relatives and community. Therefore, consuming, marketing and/or living with people who use and/or participate in the market of licit and illicit drugs can lead to situations of vulnerability that generate social and health damages ${ }^{(1)}$.

Women are involved with drugs in a variety of ways. Many live with people who use drugs and/ or participate in trafficking, especially with their family members who play the role of father, partner, ex-partner and child. Whatever the form of involvement, women are vulnerable to harm and social and health problems that have an impact on their quality of life $\mathrm{e}^{(1)}$.

Although drug use is still higher among men and is considered a typical male behavior, there is an increase in the number of women using psychoactive, licit or illicit substances. According to the World Drug Report, some 250 million people between the ages of 15 and 64 have used at least one drug in 2014. Among the drugs most commonly used by women are opioids and non-prescription tranquilizers ${ }^{(2)}$.

Data from the II National Survey on Drugs indicate a prevalence of $39.0 \%$ of women who used regular alcohol and $12.8 \%$ used tobacco in $2012^{(3)}$. The National Survey of Penitentiary Information, produced by the National Penitentiary Department, shows that the increase in the number of women incarcerated has as its main motive the participation in drug trafficking, corresponding to $63.0 \%$ of the imprisonments in $2015^{(4)}$.

Despite the moral judgment on the practices of consumption by women, it is observed that they continue to consume such substances even when they are pregnant. A national study with 394 pregnant women identified that approximately $18.0 \%$ of the interviewees used drugs of abuse during pregnancy, with the most prevalent consumption of tobacco (9.1\%) and alcohol $(6.1 \%)^{(5)}$.
During pregnancy, women present physical, psychological, hormonal and social changes, with greater susceptibility to various diseases. When associated with drug involvement, the context of vulnerability of these women is expanded, and can directly affect the relationship between the mother-fetus binomial and the experience of motherhood.

Vulnerability in health results from the integration of individual, social and programmatic aspects. The individual dimension implies that all people are vulnerable, to a greater or lesser degree. It involves particular characteristics such as age, race and sex, as well as the way of life, the level of knowledge and the ability to face the grievance. The social is directly linked to the economic structure, the availability of public policies for education, health, culture, gender relations, among others. The programmatic dimension involves institutional interventions, such as access to actions for the prevention and control of diseases and social resources existing in the area of health services coverage ${ }^{(6-7)}$.

Socio-demographic and economic factors are elements that have an impact on social and health problems or damages in the lives of individuals or groups. The social context that permeates women with low schooling, multiparous, without occupation or with low remuneration produces situations of vulnerability, and these factors result from individual, collective and contextual aspects ${ }^{(8)}$.

Therefore, understanding the factors related to the social context that influence the involvement of pregnant women with drugs can contribute to the early diagnosis of vulnerability and the planning of interventions that assist in the development of healthy pregnancy. Thus, the article has as a matter of study: is there an association between the sociodemographic and socioeconomic characteristics of pregnant women and their involvement with drugs? To answer it, the objective is to verify the association between sociodemographic conditions and the involvement of pregnant women with drugs. 


\section{Methods}

This was a cross-sectional study carried out with 268 pregnant women attended at a public maternity hospital in the city of Salvador, Brazil, between July and December 2013. Participants were included based on the following criteria: being enrolled in the unit and present conditions to interact with the researcher. Pregnant women under the age of 18 did not participate in the study. Due to the absence of specific records on monthly prenatal care, a non-probabilistic and convenience sample was chosen.

The pregnant women were approached in the waiting room of the service, while awaiting the attendance of the prenatal consultation, to clarify the objectives of the research. By agreement to participate in the study, the woman was taken to a private place where a structured, non-recorded interview was conducted, with an average duration between fifteen to twenty minutes.

Data were produced using an instrument containing as outcome variables: drug use by pregnant women at some point in life and the use of psychoactive substances by relatives; (age group, race color, marital status, religion, occupation, schooling, living conditions, financial dependence, family income and financial assistance).

The data were stored and analyzed in the Statistical Package of Social Science software version 20.0 of the Windows platform. The analysis consisted in estimating the association between the involvement with psychoactive substances and the sociodemographic conditions of the pregnant women, using Fisher's Exact Test, at the statistical significance level of $5 \%(\alpha \leq 0.05)$. In order to verify the magnitude of the associations, odds ratios and their respective 95\% Confidence Intervals (CI) were estimated.
The study respected the formal requirements contained in the national and international norms regulating research involving human beings.

\section{Results}

Table 1 presents information on the association between drug use and the sociodemographic characteristics of pregnant women. The odds ratio for drug use was 2.6 times higher for illiterate women with incomplete elementary school (OR: 2.59; CI: 0.72-9.30). The relationship between schooling and drug use showed a statistically significant difference ( $p=0.017$ ) between the groups, as well as between race and substance use $(\mathrm{p}=0.020)$. A statistically significant association $(p=0.001)$ was observed between the use of psychoactive substances and housing conditions $(\mathrm{p}=0.014)$. Women living in a rented home were $2.8 \mathrm{ti}$ mes more likely to use drugs (OR: 2.82; CI: 1.16-6.83). There were more pregnant women who used some substance and declared themselves totally financially independent (30.8\%), with income of one to three minimum wages $(40.0 \%)$ and receiving no government benefit (59.7\%).

Table 2 shows the relationship between the use of drugs by relatives/acquaintances and the sociodemographic variables of the participants. There were no statistically significant associations between these variables. Pregnant women totally dependent financially presented 2.5 times more chances to live with drug users (OR: 2.48; CI: 0.56-11.00). When associated with income, the use of psychoactive substances by acquaintances was higher among women who had between one and three minimum wages (42.2\%). Pregnant women with a family income of more than three minimum wages had 3.9 more chances to live with people using drugs (OR: 2.51; CI: 0.72-8.70). 
Table 1 - Association between drug use and sociodemographic characteristics of pregnant women

\begin{tabular}{|c|c|c|c|c|c|}
\hline \multirow{2}{*}{ Variables } & \multicolumn{2}{|c|}{ Drug use in life } & \multirow{2}{*}{$\mathbf{p}^{*}$} & \multirow{2}{*}{$\begin{array}{l}\text { Odds } \\
\text { ratio }\end{array}$} & \multirow{2}{*}{$\mathrm{CI}(95 \%)^{* *}$} \\
\hline & No $(\%)$ & Yes $(\%)$ & & & \\
\hline \multicolumn{6}{|l|}{ Age group (years) } \\
\hline$<20$ & $3(1.1)$ & $28(10.5)$ & 0.498 & & \\
\hline $20-29$ & $29(10.8)$ & $126(47.0)$ & & 0.60 & $(0.18-2.00)$ \\
\hline$>30$ & $16(6.0)$ & $66(24.6)$ & & 0.65 & $(0.18-2.29)$ \\
\hline \multicolumn{6}{|l|}{ Race } \\
\hline Black & $44(16.4)$ & 203 & 0.020 & 1.86 & $(0.35-3.38)$ \\
\hline White & $4(1.4)$ & $17(6.4)$ & & & \\
\hline \multicolumn{6}{|l|}{ Education } \\
\hline $\begin{array}{l}\text { Illiterate/Grade school in- } \\
\text { complete }\end{array}$ & $6(2.2)$ & $34(12.7)$ & 0.017 & 2.59 & $(0.72-9.30)$ \\
\hline $\begin{array}{l}\text { Grade school full/High } \\
\text { school incomplete }\end{array}$ & $5(1.9)$ & $62(23.1)$ & & 0.61 & $(0.24-1.57)$ \\
\hline $\begin{array}{l}\text { High school Full/Univer- } \\
\text { sity }\end{array}$ & $37(13.8)$ & $124(46.3)$ & & & \\
\hline \multicolumn{6}{|l|}{ Occupation $(\mathrm{n}=252)$} \\
\hline Unemployed & $11(4.4)$ & $60(23.8)$ & 0.704 & & \\
\hline Non Remunerated & $8(3.2)$ & $29(11.5)$ & & 0.65 & $(0.24-1.77)$ \\
\hline Remunerated & $27(10.7)$ & $117(46.4)$ & & 0.81 & $(0.38-1.72)$ \\
\hline \multicolumn{6}{|l|}{ Home } \\
\hline Own home & $41(15.3)$ & $147(54.9)$ & 0.014 & & \\
\hline Rented & $7(2.6)$ & $73(27.2)$ & & 2.82 & $(1.16-6.83)$ \\
\hline \multicolumn{6}{|l|}{ Economic situation $(n=263)$} \\
\hline Independent & $19(7.2)$ & $81(30.8)$ & 0.381 & & \\
\hline Totally dependente & $20(7.6)$ & $82(31.2)$ & & 1.79 & $(0.56-2.49)$ \\
\hline Partial dependency & $7(2.7)$ & $54(20.5)$ & & 1.19 & $(0.72-4.46)$ \\
\hline \multicolumn{6}{|l|}{ Family income (wages) $(n=248)$} \\
\hline$<1$ & $15(6.0)$ & $58(23.4)$ & 0.644 & & \\
\hline 1 a 3 & $18(7.3)$ & $99(40.0)$ & & 1.42 & $(0.67-3.01)$ \\
\hline$>3-$ & $10(4.0)$ & $48(19.3)$ & & 1.22 & $(0.51-2.92)$ \\
\hline \multicolumn{6}{|l|}{ Social program } \\
\hline No & $37(13.8)$ & $160(59.7)$ & 0.592 & 1.27 & $(0.58-2.80)$ \\
\hline Yes & $11(4.1)$ & $60(22.4)$ & & & \\
\hline
\end{tabular}

Table 2 - Association between the use of drugs by relatives/acquaintances and the sociodemographic characteristics of pregnant women

\begin{tabular}{lll}
\hline Variables & $\begin{array}{c}\text { Drug use by } \\
\text { family members }\end{array}$ \\
\cline { 2 - 3 } & po (\%) Yes (\%) & $\begin{array}{l}\text { Odds } \\
\text { ratio }\end{array}$ \\
\hline
\end{tabular}

Age group (years)

$\begin{array}{llll}<20 & 1(0.4) & 30(11.2) & 0.742 \\ 20-29 & 8(3.0) & 147(54.9) & 1.11(0.18-6.78) \\ >30 & 2(0.7) & 80(29.8) & 1.77(0.22-14.12)\end{array}$

Race

Black

White

11(4.1) 236(88.1) 0.329

Education

Illiterate/Grade school

incomplete

Grade school full/High

school incomplete

$\begin{array}{lll}- & 21(7.8) & 0.68(0.93-0.98)\end{array}$

High school Full/University

$7(2.6) \quad 154(57.5)$

$1.64(0.27-9.98)$

Occupation $(n=252)$

Unemployed

$2(0.8) \quad 69(27.4) \quad 0.901$

Non Remunerated

$1(0.4) \quad 36(14.3)$

$0.87(0.11-6.89)$

Remunerated

$7(2.8) \quad 137(54.3)$

$0.65(0.15-2.84)$

Home

Own home

$8(3.0) \quad 180(67.2) 1.000$

Rented

3(1.1) 77(28.7)

$1.09(0.30-3.90)$

Economic situation (n=263)

Independent

$6(2.3) \quad 94(35.7) \quad 0.352$

Totally dependent

$2(0.8) 100(38.0) \quad 2.48(0.56-11.00)$

Partial dependency

3(1.1) 58(22.1)

$1.17(0.30-4.51)$

Family income (wages) (n=248)

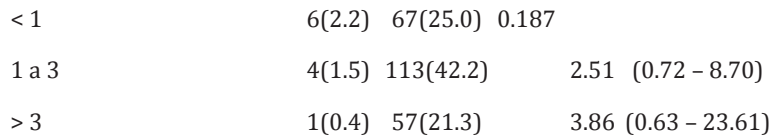

Social program

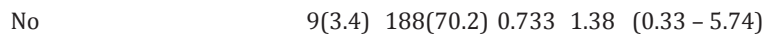

Yes 2(0.7) 69(25.7)

* Fisher's Exact Test; ${ }^{* *} \mathrm{CI}-$ Confidence interval 


\section{Discussion}

The study presents limitations on sample selection and was developed in a health service as a research field, which interferes with the generalization of the findings. For this reason, a maternity hospital was chosen that served women from all over Salvador, Brazil and the metropolitan region, in order to contemplate a more diversified sample.

When assessing drug involvement associated with the sociodemographic characteristics of pregnant women, it was observed that drug use is a broad behavior adopted by people of all age groups. The highest proportion of consumption was perceived in the interviewees under 20 years of age. It is emphasized that the onset of consumption usually occurs during adolescence, by insertion into a new social context and influence of friends, family and the environment ${ }^{(9)}$.

Regarding consumption by relatives and/or acquaintances, the proportion of pregnant women was similar for the three age groups. This can be justified by the fact that alcohol use, for example, is part of rituals of socialization and recreation in different spheres of social life, becoming common in meetings with friends or family ${ }^{(9)}$. A national study has identified the influence of permissive and stimulating behavior by parents, siblings, uncles, cousins and partners among the factors that trigger women's drug use ${ }^{(10)}$.

Black women experience situations of vulnerability due to racial and gender inequalities ${ }^{(11)}$. The relationship between race and drug use among pregnant women was observed. Being white presented itself as a protection factor for living with people who use drugs. In this context, vulnerabilities related to the use of substances can be enhanced by the existence of racial prejudice, judgment and violence. It is evident that the highest rates of violence are generally observed among married black women, which highlights gender and race inequality as a factor that increases vulnerability ${ }^{(12)}$.

There was a high proportion of pregnant women with complete primary education or incomplete secondary education who used and coexisted with drug users. It should be emphasized that low schooling may contribute to increased vulnerability to drug use, so regular school attendance is considered a protection factor ${ }^{(13)}$.

Given that individual decisions are also influenced by social factors, drug use by family members can generate domestic instability; promote situations of individual vulnerability related to conflicts, violence and breakdown of affective relationships between peers $^{(14)}$. The fragility of the bonds and the unstable domestic environment are factors that influence the continuity of the studies and the abandonment of the school. Therefore, the family destabilization caused by drug use can contribute to the maintenance of the continuous circle of vulnerabilities experienced by women.

The high proportion of unemployed pregnant women directly and indirectly involved in drugs is highlight. Survey data on the consumption of psychoactive substances reveal that the proportion of drug users is higher in the labor force compared to the general population, and that people who are unemployed or unsatisfied with their jobs are consuming alcohol, tobacco, drugs and other drugs ${ }^{(15)}$. Unemployment associated with drug use, poverty and inaccessibility to goods and services are elements that foster social vulnerability.

Pregnant women who use psychoactive substances, inserted in the informal labor market, usually have their income compromised by the financial instability that, associated with the economic crisis of the country, can affect the woman's ability to maintain the rent. This results in temporary housing, unhealthy housing or possibly street situations.

In addition to the unfavorable socioeconomic situation, low schooling, unemployment and underemployment contribute to inadequate housing conditions ${ }^{(16)}$, which directly influence the health condition of the population. The social and geographical context exerts important variations in health levels, because the characteristics of the environment and the people who live in it influence the processes of illness and death. The environment is the result of the interaction of 
historical, social, individual and environmental situations that promote manifestations in the health-disease process of its inhabitants ${ }^{(17)}$. Therefore, the housing condition is a determining factor for vulnerability to health problems and other risk situations.

It was identified that the use of drugs by the pregnant women had relation with the condition of dwelling. Both consumption among women and living with users were proportionally higher among those who lived in rented houses. The need to revert part of the rent, which is already low, for rent payment, amplifies situations of social instability ${ }^{(18)}$. These vulnerabilities, associated with drug use, can be increased at the social and individual levels. The association between drug use, domestic violence, impoverishment, social withdrawal, loss of the home and street situation is evidenced ${ }^{(19)}$.

As for family income and financial dependence, there was a higher proportion of women who used drugs, had a family income of one to three minimum wages and depended partially on the partner or relative. The current scenario of social vulnerability determined by the exclusion and marginalization of the less favored populations and the concentration of income contributes to the increase of poverty and misery of the Brazilian population ${ }^{(20)}$. The fact that women find themselves unemployed or engaging in low-paid activities, may make them economically dependent on the partner and collaborate to maintain an unsatisfactory or violent relationship.

An even greater proportion of drug use among women participating in social income transfer programs was also highlighted, which also showed greater coexistence with drug users. This can be justified by the fact that socio-welfare programs and benefits have as a priority public people in situations of extreme poverty, vulnerability and social risk.

Women involved with drugs are more susceptible to situations of vulnerability, especially in the context of maternity due to biological alterations such as preterm birth and fetal malformation; obstetric and perinatal context or gestational experience, mother- -child relationship and maternity.

Therefore, the results of this research contribute to the visibility of the drug problem in the female population, especially for pregnant women and their contexts of vulnerability, with a view to minimizing the impacts on the mother-baby binomial and improving the health care of pregnant women involved with drugs.

\section{Conclusion}

It was evidenced that different factors contribute to the occurrence of vulnerability to health among pregnant women, mainly resulting from the integration of individual and social aspects.

\section{Acknowledgements}

The Coordenação de Aperfeiçoamento de Pessoal de Nível Superior and the Conselho Nacional de Desenvolvimento Científico e Tecnológico.

\section{Collaborations}

Porto PN contributed with the design, analysis, interpretation of the data and writing of the article. Borges SAC contributed to the writing of the article. Araújo AJS, Pereira MN, Oliveira JF and Almeida MS contributed with the design. All authors contributed to the relevant critical review of the intellectual content and approval of the final version to be published.

\section{References}

1. Porto PN, Oliveira JF, Campos ACP, Pires CGS. Acesso aos serviços de saúde: fatores associados ao envolvimento de gestantes com drogas. Rev Baiana Enferm. 2015; 29(4):350-60. doi: http:// dx.doi.org/10.18471/rbe.v29i4.13832

2. United Nations Office on Drugs and Crime. World drug report [Internet]. 2016 [cited 2017 Dec. 26]. Available from: https://www.unodc.org/ documents/wdr2014/World_Drug_Report_2016_ web.pdf 
3. Laranjeira R, organizador. II Levantamento Nacional de Álcool e Drogas. São Paulo: Instituto Nacional de Ciência e Tecnologia para Políticas Públicas de Álcool e Outras Drogas; 2014.

4. Moura TW, Ribeiro NCT. Levantamento Nacional de Informações Penitenciárias. Brasília: Departamento Penitenciário Nacional; 2016.

5. Kassada DS, Marcon SS, Palagliarini MA, Rossi RM. Prevalence of drug abuse among pregnant women. Acta Paul Enferm. 2013; 26(5):46771. doi: http://dx.doi.org/10.1590/S010321002013000500010

6. Kalichman AO, Ayres JRCM. Integralidade e tecnologias de atenção à saúde: uma narrativa sobre contribuições conceituais à construção do princípio da integralidade no SUS. Cad Saúde Pública. 2016; 32(8): e00183415. doi: http:// dx.doi.org/10.1590/0102-311X00183415

7. Oviedo RAM, Czeresnia D. O conceito de vulnerabilidade e seu caráter biossocial. Interface Comun Saúde Educ. 2015; 19(53):237-49. doi: http://dx.doi.org/10.1590/1807-57622014.0436

8. Borges CC. Mudanças nas trajetórias de vida e identidades de mulheres na contemporaneidade. PsicolEstud. 2013;18(1):71-81.doi:http://dx.doi. org/10.1590/S1413-73722013000100008

9. Borsari B, Zamboanga BL, Correia C, Olthuis JV, Van Tine K, Zadworny Z, et al. Characterizing high school students who play drinking games using latent class analysis. Addic Behav [Internet]. 2013 [cited 2017 Apr. 14]; 38(10):2532-40. Available from: https://www.ncbi.nlm.nih.gov/ pubmed/23778317

10. Marangoni SR, Oliveira MLF. Triggering factors for drug abuse in women. Texto Contexto Enferm. 2013; 22(3):662-70. doi: http://dx.doi. org/10.1590/S0104-07072013000300012

11. Prestes CRS, Paiva VSF. Psychosocial approach and health of black women: vulnerabilities, rights and resilience. Saúde Soc. 2016; 25(3):67388. doi: http://dx.doi.org/10.1590/s0104129020162901

12. Lacey KK, Paranell R, Mouzon DM, Matusko N, Head D, Abelson J, et al. The mental health of US Black women: the roles of social context and severe intimate partner violence. BMJ Open [Internet]. 2016 [cited 2017 Aug. 10]; 5(1):113. Available from: http://bmjopen.bmj.com/ content/5/10/e008415
13. Ferreira VP, Silva MA, Noronha Neto C, Falbo Neto $\mathrm{GH}$, Chaves CV, Bello RP. Prevalência e fatores associados à violência sofrida em mulheres encarceradas por tráfico de drogas no Estado de Pernambuco, Brasil: um estudo transversal. Ciênc Saúde Coletiva. 2014; 19(7):2255-67. doi: http://dx.doi. org/10.1590/1413-81232014197.10012013

14. Ribeiro MR, Silva AAM, Alves MTSSB, Batista RFC, Rocha MLN, et al. Psychological violence against pregnant women in a prenatal care cohort: rates and associated factors in São Luis, Brazil. BMC Pregnancy Childbirth. 2014; 14(1):66-74. doi: https://doi.org/10.1186/1471-2393-14-66

15. Serviço de Intervenção nos Comportamentos e nas Dependências: Divisão de Estatística e Investigação e Divisão de Informação e Comunicação. Relatório anual 2013: A situação do país em matéria de drogas e toxicodependências. Lisboa: SICAD; 2014.

16. Reis LM, Uchimura TT, Oliveira MLF. Socioeconomic and demographic profile in a vulnerable community to the use of drugs of abuse. Acta Paul Enferm. 2013; 26(3):276-82. doi: http://dx.doi. org/10.1590/S0103-21002013000300012

17. Souza CL, Andrade CS. Saúde, meio ambiente e território: uma discussão necessária na formação em saúde. Ciênc Saúde Coletiva. 2014; 19(10):411322. doi: http://dx.doi.org/10.1590/1413812320141910.08992014

18. Abreu LG, Alvares LFHM, Nogueira EMC. Consumo de famílias de baixa renda no Rio de Janeiro: um estudo de segmentação baseada no orçamento familiar. Rev Adm.Made [Internet]. 2015 [citado 2017 mar. 28]; 18(3):19-39. Disponível em: http://revistaadmmade.estacio.br/index.php/ admmade/article/viewFile/1306/599

19. Ferreira LN, Bispo Júnior JP, Sales ZN, Casotti CA, Braga Junior ACR. Prevalência e fatores associados ao consumo abusivo e à dependência de álcool. Ciênc Saúde Coletiva. 2013; 18(11):340918. doi: http://dx.doi.org/10.1590/S141381232013001100030

20. Paiva AB, Mesquita ACS, Jaccoud L, Passos L. Nota técnica: $O$ novo regime fiscal e suas implicações para a política de assistência social no Brasil. Brasília: Instituto de Pesquisa Econômica Aplicada; 2016. 